\title{
INFLUENCE OF TEMPERATURE DIFFERENCE (WATER-COVER SURFACE) ON THE PERFORMANCE OF A COMPACT HEMISPHERICAL SOLAR STILL
}

\author{
B. Z. Adewole ${ }^{1, *}$, A. E. Arabambi ${ }^{2}$ and A. A. Asere ${ }^{3}$ \\ $\mathbf{1 , 2 , 3}$, DePt. of MeChanical Engineering, Obafemi Awolowo University, Ile-Ife, Osun State, NIGERIA \\ Email-addresses: ${ }^{1}$ bzadewole@oauife.edu.ng, ${ }^{2}$ yemiarabambi@gmail.com \\ 3aaasere77@yahoo.co.uk
}

\begin{abstract}

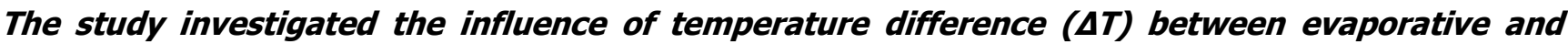
condensing surface temperature on water productivity of hemispherical solar still. The still was developed, tested and evaluated under the climatic conditions of Ile-Ife, Nigeria, to obtain an average distillate yield per hour per day for different combination of basin temperature, water temperature, transparent cover temperature, ambient temperature and solar intensity. Results indicated a decrease in the hourly water yield as (UT) increases. Regression analysis revealed that $\Delta T$ has no significant influence on the hourly water yield $(P>0.05)$. Maximum water productivity was obtained for a low condensing surface temperature and a high evaporative surface temperature. The study concluded that the improvement on water productivity of solar still can be achieved by enhancing the evaporative and condensing surface temperature. Methods for obtaining higher evaporating temperature should be sought in order to boost water productivity of solar stills.
\end{abstract}

Keywords: Temperature difference, Evaporative surface, Condensing surface, Hourly water yield, Heat losses.

\section{INTRODUCTION}

Clean water is essential for good health. The quality of available safe drinking water is of paramount importance to man. Over $97 \%$ of water available on the earth's surface is salty [1] and environmental pollution caused predominantly by anthropogenic activities is also contributing to the degradation of freshwater resources. World Health Organization reported that $78 \%$ and $96 \%$ of the rural and urban populations respectively, used unclean drinking water on a global scale respectively [2]. About, 4 billion cases of diarrhea are also reported annually in developing countries with $88 \%$ of them being ascribed to the use of unclean water, and insufficient sanitation and hygiene [2]. This indicates the need for interventions that aim at providing clean water in these countries. In view of this, the sustainable development goals incorporate a target that countries without access to safe and affordable drinking water should have access by 2030 [3]. Indeed, this goal can be achieved through a multi-faceted approach which includes the development of appropriate technologies and improvement of the existing technologies for water desalination and purification.

Various purifications and desalination technologies had been employed to provide clean potable water from saline and polluted water. They include multistage flash (MSF), multiple effect (ME), vapour compression (VC), reverse osmosis (RO), ion exchange, electrodialysis, phase change and solvent extraction technology [4]. However, for the production of a small amount of potable clean water, conventional simple desalination solar still provides the cheapest option. There are various solar stills in existence. They include: Single basin type, single effect basin stills, multiple effect stills, single or multiple wicks stills, inclined tray or stepped stills, multistage-flash distillation stills, solar film covered stills and solar concentration stills [5-7]. Others include spherical solar still, pyramid solar still, 
hemispherical solar still, double basin glass solar still, concentrator coupled single slope solar still, tubular solar still and tubular solar still coupled with pyramid solar still [8-12].

In a solar still, solar radiation passes through the transparent cover to the water basement where it is absorbed and emitted as heat to heat the body of water above it, leading to evaporation of water at a higher temperature. The evaporated water in turn, is condensed on the cooler underside of the transparent cover and the distilled water is collected through a tray on the side wall of the system. The temperature at which water evaporated to the glass cover and condensed to produce distillate plays an important role in determining the amount of distilled output received from the solar still. These two temperatures depend on the operating temperature range and it holds good for upward heat flow in an enclosed air space [13]. Further, the difference between both temperatures is independent of average distance between the condensing and evaporating surfaces and it can increase or decrease [13]. In evaluating thermal performance of a conventional solar distillation system, [14] developed a thermal model using basic internal heat and mass relations. The model predicted the hourly distillate output using hourly evaporation, convective heat transfer coefficients and latent heat of vaporization of water. The dominance of evaporative fraction within $32-37^{\circ} \mathrm{C}$ was reported and it varies according to the water depth. Effect of water capacity on internal and external heat transfer for a solar distillation system was also investigated by [4]. It was found that the internal and external heat transfer depends significantly on the water capacity in the basin.

In the analysis of solar stills by various authors, a little consideration had been given to the difference between evaporative and condensing surface temperature in optimizing distillate yields from solar stills. The objectives of this study are to investigate the influence of temperature difference $(\Delta T)$ between water and transparent cover on the hourly water yield and to examine the amount of heat obtainable for the production of hourly water yield in the hemispherical solar still.

\section{MATERIALS AND METHODS}

\subsection{Construction and Fabrication details}

The compact hemispherical solar still was designed and constructed using locally available materials. Figure 1 shows detailed drawing of the solar still basin while Figure 2 shows the cross-sectional view of the hemispherical solar still supported by wooden frame. The still consists of a basin, wooden stand, insulator, condensate channel, transparent cover, collecting tank as well as supply and delivery pipe systems. The volume of the basin and the surface area of the transparent cover are $0.076 \mathrm{~m}^{3}$ and $0.603 \mathrm{~m}^{2}$ respectively. The basin was fabricated with mild steel sheet and insulated with $25 \mathrm{~mm}$ thick rock wool $\left(\mathrm{k}=0.045 \mathrm{~W} / \mathrm{m}^{2} . \mathrm{K}\right)$ to prevent heat losses from the wooden sides to the surrounding. Solar radiation through semi-circular transparent cover was transferred into the basin irrespective of the position of the sun.

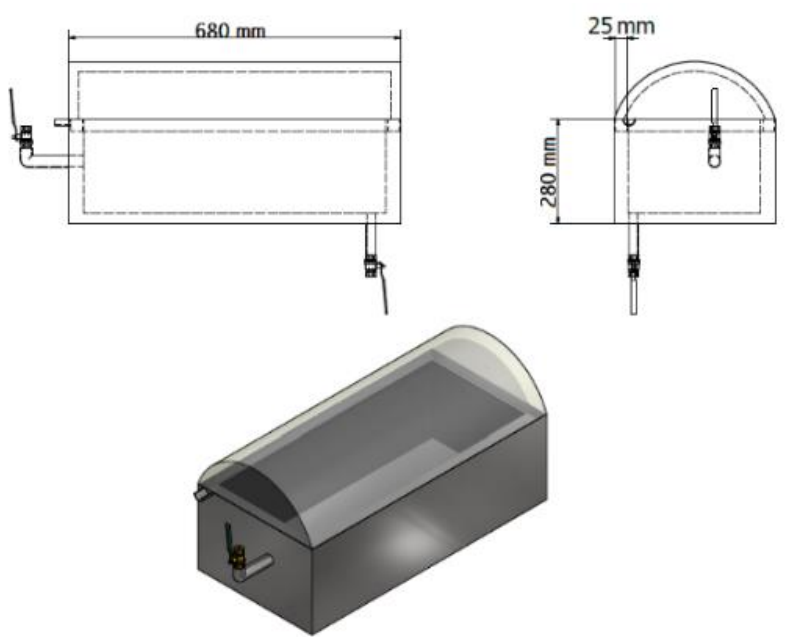

Figure 1: Detailed drawing of the solar still basin
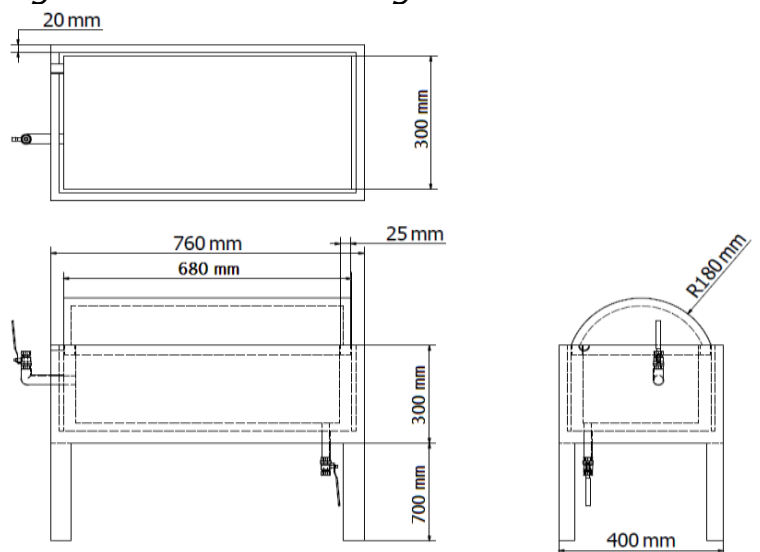

Figure 2. Cross-sectional view of the hemispherical solar still supported by wooden frame

The cover was made from transparent plastic with a base dimension of $720 \mathrm{~mm} \times 360 \mathrm{~mm}$ and a radius of $180 \mathrm{~mm}$. The transparent plastic was selected due to its capacity to produce greenhouse effect inside the still and its ability to transmit over $60 \%$ incident radiation in the visible range. Other properties considered during fabrication include low cost, 
flexibility, reduced vulnerability to mechanical damages and lightweight.

\subsection{Theoretical analysis}

\subsubsection{Energy received by the solar still}

The energy received by the solar still was determined by equation (1) given by [15]:

$$
E=I . A \text {. }
$$

Where $I\left(W / \mathrm{m}^{2}\right)$ is the direct radiation received by the surface and $A\left(\mathrm{~m}^{2}\right)$ is the effective area of the surface.

\subsubsection{Heat gained by water}

The heat gained by water was computed according to equation (2):

$$
H=m c(\delta T)
$$

where $\mathrm{m}$ is the mass of water $(\mathrm{g}), \mathrm{c}$ is the specific heat of water $\left(\mathrm{J} / \mathrm{kg}^{\circ} \mathrm{C}\right)$ and $\delta T$ is the change in water and transparent cover temperature $\left({ }^{\circ} \mathrm{C}\right)$.

\subsubsection{Heat loss due to convection}

This includes the convective heat loss from the hot water surface in the still to the glass; and from the glass cover to the ambient air. It was determined using equation (3):

$$
Q_{c}=h_{c} A_{w}\left(T_{w}-T_{c}\right)
$$

where $Q_{c}$ is the heat transferred per unit time $(W), h_{c}$ is the convection heat transfer coefficient $\left(\mathrm{W} /\left(\mathrm{m}^{2} \cdot \mathrm{K}\right)\right.$, $A_{w}$ is the area of the water surface, $T_{w}$ is the temperature of water and $T_{c}$ is the temperature of the transparent cover. In computing the heat transfer coefficient, [16] and [17] employed the empirical relation of equation (4):

$$
h_{c}=0.884\left(T_{w}-T_{c}+\frac{P_{w}-P_{c}}{268.9-P_{w}} T w\right)^{1 / 3}
$$

Where $P_{w}$ and $P_{c}$ are the saturation partial pressures of water vapour $\left(\mathrm{N} / \mathrm{m}^{2}\right)$ at water and transparent cover temperature respectively. So, $\mathrm{P}_{\mathrm{w}}$ and $\mathrm{P}_{\mathrm{c}}$ are defined mathematically by equation (5) according to [18] as:

$P_{w}=e^{\left(25.317-\frac{5144}{T_{w}}\right)}$ and $P_{c}=e^{\left(25.317-\frac{5144}{T_{c}}\right)}$

The convective heat loss $\left(\mathrm{Q}_{c}\right)$ from the transparent cover to the ambient air was determined by equation (6) given by [17]:

$$
\mathrm{Q}_{c a}=\mathrm{h}_{\mathrm{ca}}\left(\mathrm{T}_{\mathrm{c}}-\mathrm{T}_{\mathrm{a}}\right)
$$

Where $h_{c a}$ is the forced convective heat transfer coefficient expressed in equation 7:

$$
\mathrm{h}_{\mathrm{ca}}=2.8+3.6 \mathrm{v}
$$

where $v$ is the wind speed in $\mathrm{m} / \mathrm{s}$. Average wind speed and ambient temperature for the study location were obtained as $2 \mathrm{~m} / \mathrm{s}$ and $26.2^{\circ} \mathrm{C}$ respectively.

\subsubsection{Evaporative heat loss}

Mathematical expression for the computation of evaporative heat loss $\left(Q_{e}\right)$ is given by [19] and expressed in equation (8):

$$
Q_{e}=0.01623 h_{c}\left(P_{w}-P_{c}\right)
$$

\subsubsection{Heat loss due to radiation}

Heat loss due to radiation from water surface to the transparent cover is expressed as:

$$
\mathrm{Q}_{\mathrm{r}}=\varepsilon_{\text {eff }} \sigma A_{w}\left(T_{w}^{4}-T_{c}^{4}\right)
$$

where $\mathrm{Q}_{r}$ is the heat transfer per unit time $(\mathrm{W}), \sigma$ is the Stefan Boltzmann constant $\left(5.6703 \times 10^{-8}\right.$ $\left(\mathrm{W} / \mathrm{m}^{2} \cdot \mathrm{K}^{4}\right), \mathrm{T}_{\mathrm{w}}$ is the water temperature $\left({ }^{\circ} \mathrm{C}\right), \mathrm{T}_{\mathrm{c}}$ is the transparent cover temperature,

$A_{\mathrm{w}}$ is the area of the water surface and $\varepsilon_{e f f}$ is the effective emissivity expressed as:

$$
\varepsilon_{e f f}=\frac{1}{\frac{1}{\varepsilon_{W}}+\frac{1}{\varepsilon_{c}}-1}
$$

\subsubsection{Hourly distillate output}

The hourly distillate output from the solar still was evaluated by equation (11):

$$
m_{w}=\frac{A_{w} Q_{e} 3600}{h_{f g}}
$$

where $m_{w}$ is the mass of hourly distilled water $(\mathrm{kg})$, $\mathrm{h}_{\mathrm{fg}}$ is the latent heat of evaporation, $\mathrm{J} / \mathrm{kg}$.

\subsubsection{Still efficiency}

The still efficiency was determined by equation (12). $\mathrm{Q}\left(\mathrm{W} / \mathrm{m}^{2}\right)$ is the amount of heat utilized by the solar still for obtaining total $\mathrm{kg}$ of distilled water per day and $\mathrm{H}_{\mathrm{T}}$ is the insolation on the horizontal surface of solar still per day.

$$
\eta=\frac{Q}{H_{T}} \times 100
$$

\subsection{Experimentation}

The experiment was set up to evaluate the performance of the solar still under climatic conditions of Ile-Ife, Nigeria (Lattitude $7.517722{ }^{\circ} \mathrm{N}$, Longitude $4.526348^{\circ} \mathrm{E}$ ). The still basin was filled with sea water obtained from Elegushi beach, Lagos Nigeria. The experiment was performed for three weeks in the month of March and it covered a period of nine hours from $8 \mathrm{am}$ to $5 \mathrm{pm}$ with readings recorded at one-hour interval. Data for solar intensity was measured using Global Radiation Meter (GRM 100), ambient temperature, basin temperature, water temperature and transparent cover temperature were measured using ZTT industrial Handheld, IR Thermometer, wind speed was measured using Thermo Anemometer (PROVA 
Instrument, AVM-01), time and water yield were measured using stopwatch and measuring cylinder respectively. Average value of each parameter was determined and recorded. Table 1 shows the accuracy of Instruments used in this study with percentage errors.

\section{RESULTS AND DISCUSSION}

\subsection{Average ambient temperature and solar intensity}

The variation of ambient temperature and solar irradiance during the time of the experiment are shown in Figure 3. It is observed that the average ambient temperature is higher than $27^{\circ} \mathrm{C}$ at 8 am due to high solar irradiance of $290 \mathrm{~W} / \mathrm{m}^{2}$. Solar irradiance increases from $8 \mathrm{am}$ in the morning to reach a maximum value of $1203 \mathrm{~W} / \mathrm{m}^{2}$ at $1 \mathrm{pm}$ and then gradually decreases to $145 \mathrm{~W} / \mathrm{m}^{2}$ at $5 \mathrm{pm}$. For the current design of hemispherical solar still, Figure 3 shows that in the month of March, a maximum ambient temperature of $48.7^{\circ} \mathrm{C}$ at a solar intensity of $1203 \mathrm{~W} / \mathrm{m}^{2}$ could be obtained.

\subsection{Effects of water temperature, basin temperature and transparent cover temperature on hourly water yield}

Figure 4 shows the profiles of the average solar still, water temperature, basin temperature and transparent cover temperature at different time intervals. The transparent cover temperature increases to the maximum value of $43.3^{\circ} \mathrm{C}$ at $2 \mathrm{pm}$ and then decreases gradually to $30.2^{\circ} \mathrm{C}$ at $5 \mathrm{pm}$ due to gradual decrease of solar irradiance.

Water and basin temperature profiles reach a maximum of $48.7^{\circ} \mathrm{C}$ and $50.2^{\circ} \mathrm{C}$ respectively at $1 \mathrm{pm}$ when the solar irradiance is at maximum. The variation of hourly water yield with the cover, basin, and water temperatures from 8 am to $5 \mathrm{pm}$ shows that the distilled water started accumulating at $10 \mathrm{am}$ immediately the basin and water temperatures rise above $30^{\circ} \mathrm{C}$. Condensation rate and water yield are observed to increase from $2 \mathrm{pm}$ to $5 \mathrm{pm}$ as the transparent cover, water and basin temperatures decreases.

Table 1: Instruments Accuracy with Percentage Errors

\begin{tabular}{lccc}
\hline Instruments & Accuracy & Ranges & $\%$ error \\
\hline Solarimeter & $\pm 1 \mathrm{~W} / \mathrm{m}^{2}$ & $0-2500 \mathrm{~W} / \mathrm{m}^{2}$ & 2.5 \\
Digital Infrared thermometer & $0.1{ }^{\circ} \mathrm{C}$ & $-50{ }^{\circ} \mathrm{C}$ to $550{ }^{\circ} \mathrm{C}$ & 1.5 \\
Digital anemometer & $\pm 0.01 \mathrm{~m} / \mathrm{s}$ & $0-45 \mathrm{~m} / \mathrm{s}$ & 0.1 \\
Measuring cylinder & \pm 0.5 & $0-100 \mathrm{ml}$ & 0.5 \\
Digital pH meter & \pm 0.05 & $0.00-14.00$ & 0.5 \\
TDS meter & \pm 0.3 & $0-1320 \mathrm{mg} / \mathrm{dm}^{3}$ & 2 \\
Potable conductivity meter & \pm 0.3 & $0.00-19.99 \mu \mathrm{s} / \mathrm{cm}$ & 1 \\
\hline
\end{tabular}

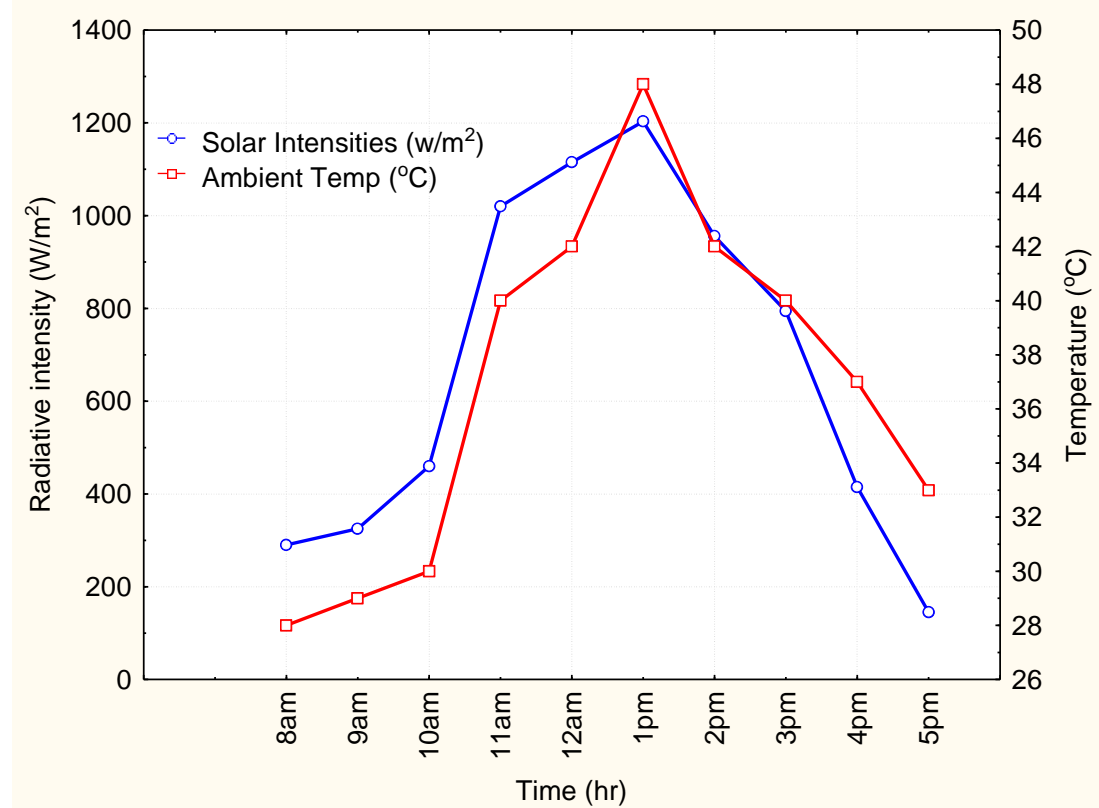

Figure 3: Diurnal variation of ambient temperature and solar irradiance from $8 a m$ to $5 p m$ during the experiment 


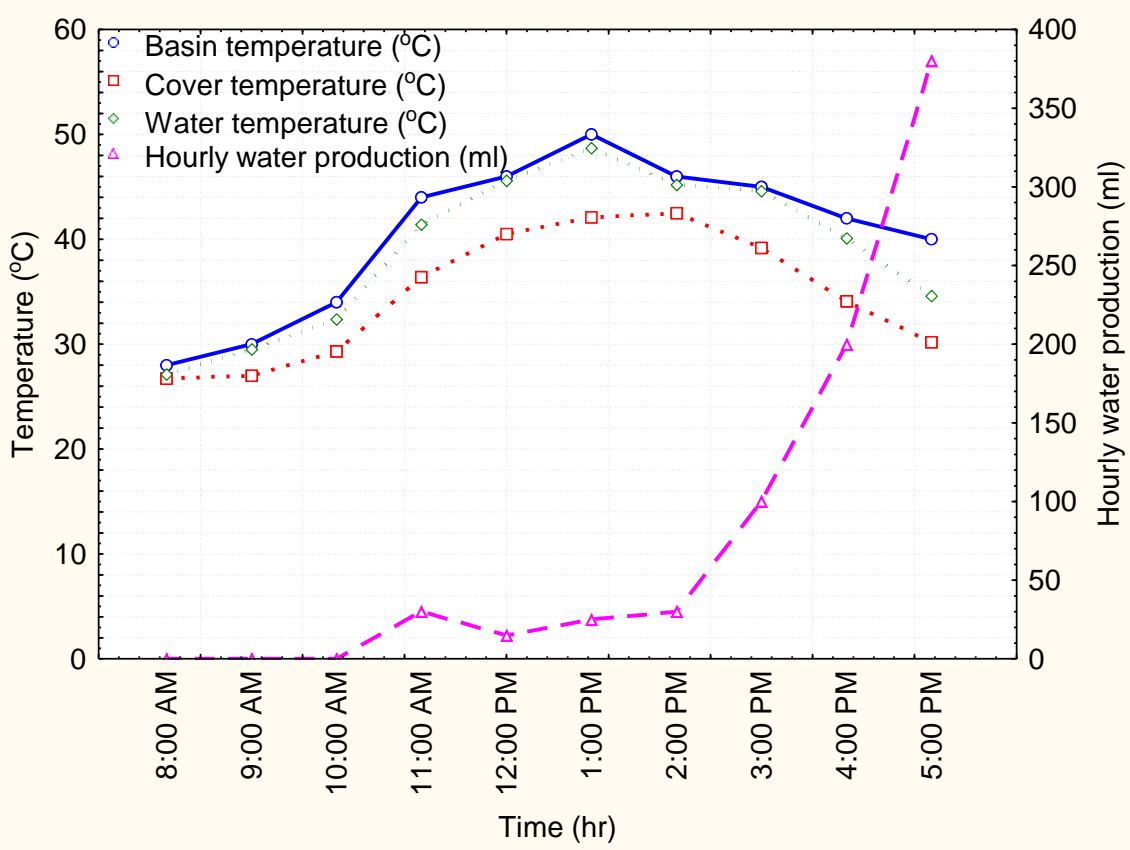

Figure 4: Diurnal variation of basin temperature, water temperature, inner transparent cover temperature and hourly water production from 8 to $5 \mathrm{pm}$

\subsection{Temperature difference between water and transparent cover}

This section investigates the difference $(\Delta T)$ between water temperature, which gives off evaporative surface temperature and the inner transparent cover temperature, which gives off the condensing surface temperature. Figure 5 displays the influence of temperature difference $(\Delta T)$ between water and inner transparent cover on the hourly water yield. It is interesting to note that as $\Delta T$ increases, hourly water yield reduces. Hourly water yield is higher for lower $\Delta T$ and lower for higher $\Delta T$. Throughout the time intervals, evaporating temperature is higher than the condensing surface temperature leading to high water evaporation from the basin to the transparent cover. During this period, the rate of condensation is low. As the condensation sets in between 3 and $5 \mathrm{pm}$, both evaporating and condensing surface temperature decrease but the condensing surface temperature is far lower than the evaporating surface temperature. As the day tends toward evening (around $5 \mathrm{pm}$ ), lower temperature difference is observed between the evaporating and the condensing surface temperature, leading to higher hourly water yield. The regression analysis of $\Delta T$ against hourly water yield, however, indicates no significant effect $(P>0.05) . \Delta T$ only accounts for $26.8 \%$ of hourly water yield $\left(r^{2}=\right.$ 0.2675).

\subsection{Heat transfer analysis}

Table 2 displays the relationship between heat received, heat losses and heat utilized by the hemispherical solar still under study. The discrepancy between energy received and energy utilized by the solar still is due to heat losses from the hot water surface to the transparent cover. Calculated values for hourly evaporative heat losses are very negligible. The rate of heat losses by convection and radiation are also insignificant.

In Figure 6, there is no clear difference between heat received and heat utilized by the solar still due to very low convective and radiative heat losses. Nearly all the heat received are converted and used for the production of water distillate. Heat analysis indicates an approximately $3.5 \mathrm{~kW} / \mathrm{m}^{2}$ of thermal energy for the production of 5.5 litres of water. 


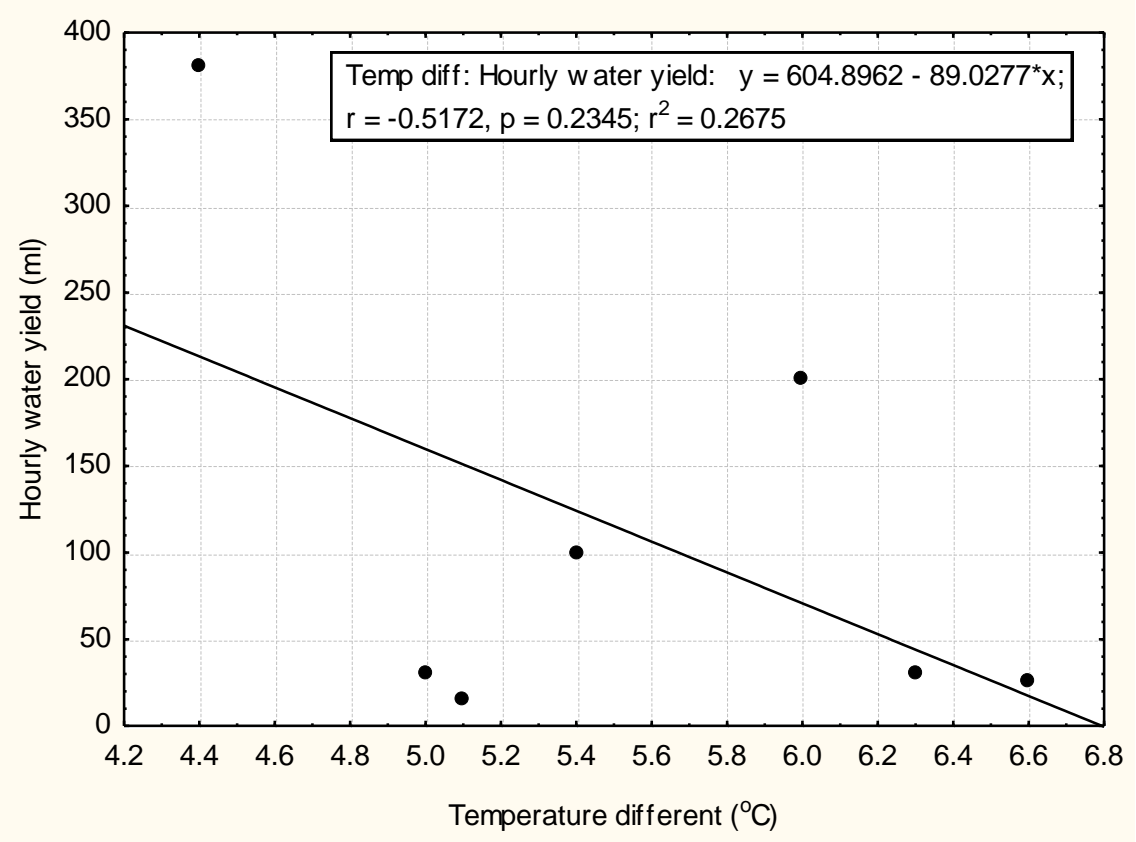

Figure 5: Scatter plot of hourly water yield against $\Delta T$

Table 2: Estimation of heat utilized and heat losses by the solar still

\begin{tabular}{ccccccc}
\hline Time & $\begin{array}{c}\text { Solar } \\
\text { Intensity } \\
\left(\mathrm{W} / \mathrm{m}^{2}\right)\end{array}$ & $\begin{array}{c}\text { Received Energy } \\
\text { by the solar still } \\
\left(\mathrm{W} / \mathrm{m}^{2}\right)\end{array}$ & $\begin{array}{c}\mathrm{h}_{\mathrm{c}} \\
\left(\mathrm{W} / \mathrm{m}^{2} . \mathrm{k}\right)\end{array}$ & $\begin{array}{c}\text { Heat losses due } \\
\text { to convection } \mathrm{Q}_{\mathrm{cw}} \\
\left(\mathrm{W} / \mathrm{m}^{2}\right)\end{array}$ & $\begin{array}{c}\text { Heat losses due } \\
\text { to radiation } \\
\mathrm{Q}_{\mathrm{r}}\left(\mathrm{W} / \mathrm{m}^{2}\right)\end{array}$ & $\begin{array}{c}\text { Heat utilized } \\
\text { by the solar } \\
\text { still }\left(\mathrm{W} / \mathrm{m}^{2}\right)\end{array}$ \\
\hline $8 \mathrm{am}$ & 290 & 147.61 & 0.652 & 0.053 & 0.000166 & 147.557 \\
$9 \mathrm{am}$ & 325.1 & 165.48 & 1.199 & 0.612 & 0.001207 & 164.867 \\
$10 \mathrm{am}$ & 460 & 234.14 & 1.289 & 0.815 & 0.001951 & 233.323 \\
$11 \mathrm{am}$ & 1020 & 519.18 & 1.511 & 1.541 & 0.006318 & 517.633 \\
$12 \mathrm{pm}$ & 1115 & 567.54 & 1.521 & 1.582 & 0.008729 & 565.949 \\
$1 \mathrm{pm}$ & 1203 & 612.34 & 1.657 & 2.231 & 0.013272 & 610.096 \\
$2 \mathrm{pm}$ & 956 & 486.60 & 1.632 & 2.097 & 0.012373 & 484.491 \\
$3 \mathrm{pm}$ & 794 & 408.15 & 1.550 & 1.708 & 0.008527 & 406.434 \\
$4 \mathrm{pm}$ & 415 & 211.24 & 1.605 & 1.965 & 0.006592 & 209.268 \\
$5 \mathrm{pm}$ & 145 & 73.805 & 1.448 & 1.380 & 0.003214 & 72.502 \\
\hline
\end{tabular}

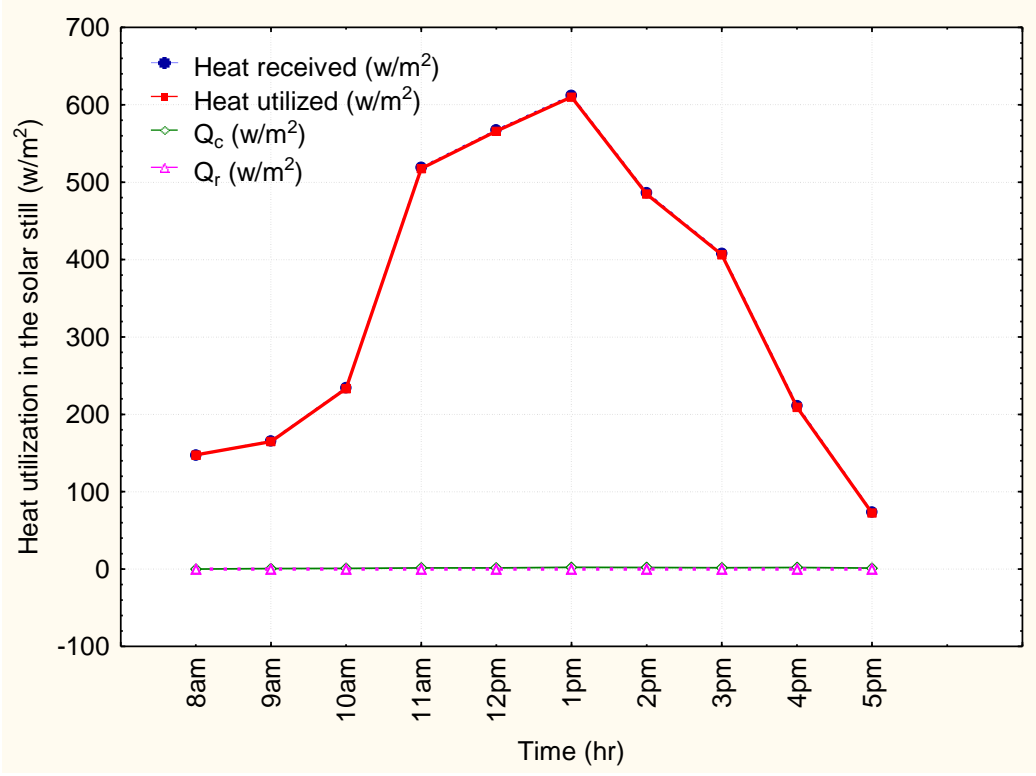

Figure 6: Plot of heat received, heat utilized and heat losses by the solar still 


\subsection{Solar still efficiency}

The present hemispherical solar still is further assessed by comparing its efficiency with those of the existing solar stills in the literature. The conventional solar still by [16] had an efficiency between 14.9 and $34 \%$ while modified solar stills such as tilted wick type [6]; hemispherical solar still [20]; continuous flow inclined solar still [21]; triangular solar still [22], etc., had maximum efficiency between $50-60 \%$ in the open literature. Under Nigerian meteorological conditions, single basin solar still tested at Makurdi [23] had an efficiency of $58 \%$, double slope solar still tested in Lagos at $2 \mathrm{~cm}$ depth [24] had an efficiency of $25.3 \%$. The present hemispherical solar still with black painted basin has an efficiency of $51 \%$. The efficiency of the solar still is in accordance with those of modified solar stills with a maximum value between 50 and $60 \%$.

\subsection{Discussion}

Obtained results show that the hemispherical solar still can be used to produce clean and affordable drinking water that will alleviate harmful effects of polluted water in developing countries. Improvements on water productivity of solar still can be achieved by enhancing evaporative and condensing surface temperature. Methods for obtaining higher evaporating temperature should be sought so as to ensure high evaporation of water from the water basin to the cover surface. Such evaporated water will be condensed to give higher distillate yield.

Technical data such as solar irradiance, ambient temperature, basin temperature, water temperature and cover temperature can be used to design solar still in developing countries with similar geographical and climatic conditions. Such data can be optimised and scaled up to produce clean water from brackish water in other to meet Sustainable development goals by 2030.

The insignificant relationship between hourly water yield and the temperature difference $(\Delta T)$ between evaporative and condensing surfaces is attributed to the dependence of $\Delta \mathrm{T}$ on the solar irradiance, evaporating surface and the condensing surface temperature. Hourly water yield depends on these parameters rather than the temperature difference between them.

Calculation of energy received, energy losses and energy utilized by the solar still are applicable for the design, construction and optimization of new solar still in communities in developing countries with similar climatic conditions. Such solar still could be used to produce clean water.

\section{CONCLUSION}

The influence of temperature difference $(\Delta T)$ between water and transparent cover and the quality of clean water produced by a compact hemispherical solar still have been investigated. The results indicated that the temperature difference $(\Delta \mathrm{T})$ between evaporative and condensing surfaces has no major influence on the hourly water yield. Hourly water yield was found to depend on solar irradiance, evaporating surface and condensing surface temperature rather than the temperature difference between them. It is confirmed in the study that $\Delta T$ only accounted for one-fourth of the water distillate yield in the solar still. The study concluded that the maximum water productivity of solar still could be obtained at a low cover (condensing) temperature and at a high water (evaporative) temperature. The thermal energy of the solar still could be maximized for higher water productivity by reducing convection and evaporation losses from hot water surface to the transparent cover.

\section{REFERENCES}

[1] Apurba, L. Exergetic analysis of basic type solar still. Engineering Science and Technology International Journal, Vol. 21, 2018, pp. 99-106.

[2] World Health Organisation. Total dissolve solid in drinking water. Background document for development of WHO Guidelines for drinkingwater quality, WHO/SDE/WSH/03.04/2016. Originally published in Guidelines for drinkingwater. $2^{\text {nd }}$ ed. Vol 2, Health criteria and other supporting information, WHO, Geneva. Accessed May 17, 2017.

[3] Sustainable Development Goal Fund (2019). Goal 6, Clean water and sanitation. Available online at https://water.sdg/fund.org/goal-6-clean-waterand-sanitation. (Accessed on 9 August, 2019).

[4] Varun raj, S., Muthu, A. M. Design and Analysis of Solar Still. Materials Today Proceeding, Vol. 4, pp. 9179-9185, 2017.

[5] Abhay, A., Rana, R.S., Pankaj, K.S. Heat transfer coefficient and Productivity of a single shape single basin solar still in Indian climatic condition: Experimental and theoretical comparison. Resource Efficient Technologies, Vol. 3, pp. 446482., 2017. 
[6] Mahdi, J. T., Smith, B. E., Sharif, A. O. An experimental wick-type solar still system: design and construction, Desalination, Vol. 267, Number 2-3, pp. 233-238, 2011.

[7] Naga, S.S., Srilalitha, S.S., Thotakura, A.S., Sai Phanindra, D.K., Ajay, P. Modelling and Analysis of Single Solar still at Different Water Depth. Aquatic Procedia, Vol. 4, pp. 1477-1482, 2015.

[8] Omara, Z.M., Eltawil, M.A., El Nashar, E.S.A. A new hybrid desalination system using wick solar still and evacuated solar water heater. Desalination, Vol. 325, pp. 56-64, 2013.

[9] Ahsan, A., Fukuhara, T. Condensation mass transfer in unsaturated humid air inside tubular solar still. Annual Journal of Hydraulic Engineering, Japan Society of Civil Engineers, Vol. 53, pp. 97-102, 2009.

[10] Ismail, B. I. Design and performance of a transportable hemispherical solar still. Renewable Energy, Vol. 34, Number 1, pp. 145-150, 2009.

[11] Ahsan, A., Islam, K. M. S., Fukuhara, T., Ghazali, A. H. Experimental study on evaporation, condensation and production of a new tubular solar still. Desalination, Vol. 260, Number 1-3, pp. 172-179, 2010.

[12] Arunkumar, T., Jayaprakash, R., Denkenberger , D. An experimental study on a hemispherical solar still. Desalination, Vol. 286, pp. 342-348, 2012.

[13] Twari, A.K. and Twari, G.N. Effects of water depths on heat and mass transfer in a passive solar still in summer climatic condition. Desalination, Vol. 195, pp. 78-94, 2006.

[14] Duncle, R.V. Solar water distillation. The roof type still and a multiple effect diffusion still. In Solar Desalination for $21^{\text {st }}$ Century: A review of Technologies and Research on Desalination Coupled to Renewable Energies, 1 ed, Springer, 2007, pp. 50-80.

[15] Pelece, I., Ziemelis, I., ILjins, U. Surface temperature distribution and energy gain from semi-spherical solar collector. In solar Thermal Applications, World Renewable Energy Congress, Linkoping, Sweden, 2011, Pp.3913-3920.
[16] Tiwari, A. K., Tiwari, G. N. Thermal modelling based on solar fraction and experimental study of the annual and seasonal performance of a single slope passive solar still: The effect of water depth. Desalination, Vol. 207, Number 1-3, pp. 184-204, 2003.

[17] Nwokoye, A. O. C. Solar Energy Technology, Other Alternative Energy Resources, and Environmental Science. Booksmith House, Harmony Place, Anambra State, Nigeria, 2006, Pp. 300-308.

[18] Abdullah, S., Badranb, O., Abu-Khader, M. M. Performance evaluation of a modified design of a single slope solar still. Desalination, Vol. 219, pp. 222-230, 2008.

[19] Malik, M. A. S., Tiwari, G. N., Kumar A., Sodha, M. S. Solar Distillation," Pergaman Press, Oxford, USA, 1982; pp. 208-332.

[20] Arunkumar, T., Vinothkumar, K., Amimul-Ahsan, J.R., Sanjay, K. Experimental Study on Various Solar Still Designs. ISRN Renewable Energy, Article ID 569381, pp. 1-10, 2012.

[21] El-Agouz, S.A., El-Samadony, Y.A.F., Kabeel, A.E. Performance evaluation of a continuous flow inclined solar still desalination system. Energy Conversion and Management, Vol. 101, pp. 606615, 2015.

[22] Riahi, A., Yusof, K. W., Singh, B., Singh, M., Olisa, E., Sapari, N., Isa, M. H. The performance investigation of triangular solar stills having different heat storage materials. International Journal of Energy Environment Engineering, pp. 1-7, 2015.

[23] Okibe, E. A., Fadoo, U. Investigation of the Effect of Angle of Cover Inclination on the Yield of a Single Basin Solar Still under Markurdi Climate. International Journal of Engineering and Sciences, Vol. 2, pp. 131-138, 2013.

[24] Babalola, T. A., Boyo, A. O., Kesinro, R. O. Effects of water depth and temperature on the productivity of a double slope solar still. Journal of Energy and Natural Resources, Vol. 4, pp. 1-4, 2015. 